\title{
Morphometric and meristic analyses of Randall's threadfin bream Nemipterus randalli Russell, 1986 along the Indian coast
}

\author{
MURUGESAN SRIHARI, SURAJ KUMAR PRADHAN, ANNAM PAVAN-KUMAR, SHASHI \\ BHUSHAN, BINAYA BUSHAN NAYAK, G. B. SREEKANTH* AND ZEBA JAFFER ABIDI \\ ICAR-Central Institute of Fisheries Education, Mumbai - 400 061, Maharashtra, India \\ ${ }^{*}$ ICAR-Central Coastal Agricultural Research Institute, Old Goa - 403 402, Goa \\ e-mail: zjabidi@cife.edu.in
}

\begin{abstract}
Nemipterus randalli Russell, 1986 is one of the commercially important demersal fish in Indian waters. The present study was designed to understand the morphometric and meristic variations between the stocks of $N$. randalli along the Indian coast. A total of 450 samples were collected from 5 maritime states during September to November 2018. A total of 19 morphometric and 9 meristic traits were extracted and subjected to statistical analyses. Factor analysis showed that morphometric characteristics like eye diameter, head length, pre-pectoral length, post-orbital length, anal fin length and caudal peduncle depth were significant in separating the stocks. Discriminant function analysis showed a high re-classification success rate of $80.43 \%$. Kruskal-Wallis test of meristic traits revealed lack of difference between the stocks. Results indicated the presence of different phenotypic stocks along the Indian coast and therefore the need for separate management strategies for sustaining the catch of $N$. randalli in the future.
\end{abstract}

Keywords: Demersal fish, Factor analysis, Management, Phenotypic plasticity, Stock

Stock identification is a central theme in fisheries science, which involves the study of self-sustaining components within natural populations (Cadrin et al., 2014). It plays a critical role in fisheries management and forms the basis of stock assessment models. Fish stocks are identified based on differences in stock characteristics. Environmental, temporal and spatial features can be used to differentiate the stock of a particular species. Detailed information is needed to distinguish between the stocks to warrant separate management practices, especially with the fish populations having complex spatial structures due to larval dispersal. The information on stock structure of fish combined with the life history parameters should be utilised to develop management strategies and promote judicious exploitation of fish species (Jennings et al., 1998; Denney et al., 2002).

The differences in the phenotypic traits may allow us to differentiate the stocks even when their geographical distribution overlaps (Swain and Foote, 1999). Morphological characters such as morphometrics and meristic have been traditionally involved in fisheries biology to describe various categories of fish (Utter, 1981). These characters have been frequently employed in the stock delineation of fish (Silva, 2003; Sajina et al., 2013). Morphometric characters show ontogenic changes associated with allometric growth, which is influenced by environmental parameters (Gould, 1966), whereas, meristic differences between fish stocks may be influenced by genetic or environmental parameters or both, in unknown proportions (Swain et al., 2005). As long as environmental factors are taken into account in the stock identification findings, the use of non-genetic techniques should not be questioned (Campana and Casselman, 1993).

Threadfin breams are one of the significant contributors to the demersal fisheries of India. It contributed nearly $4.29 \%$ (1.53 lakh $\mathrm{t}$ ) of the total marine catch and they are mainly targeted by trawls (CMFRI, 2020). Nemipterus japonicus and Nemipterus randalli are the two major nemipterid species commonly landed along the Indian coast. The Nemipterids have gained commercial importance due to their high flesh content, good flavour, presence of white meat and wide use for the preparation of surimi and surimi-based products (Rajesh et al., 2014). Fish stock characterisation and correct taxonomic identification of species are fundamental for successful fisheries management. However, only limited studies have been conducted on the stock identification of $N$. randalli (Joseph and Jayasankar, 2001). Hence, the present study was undertaken to analyse the stock variation in Nemipterus randalli Russell, 1986 based on the morphometric and meristic analyses from the samples collected along the Indian coast. 
Samples of $N$. randalli $(\mathrm{N}=450)$ were collected from Maharashtra (Mumbai), Goa (Mormugao) and Kerala (Kochi) from the west coast and Tamil Nadu (Thoothukudi) and Andhra Pradesh (Visakhapatnam) from the east coast of India between September to November, 2018 (Fig. 1; Table 1). Locations were identified based on the availability of samples and sufficient latitudinal separation. The specimens were washed, cleaned and placed on a graph sheet to provide calibration and the images were captured with a digital camera. The images (.jpg) were converted to .tps format with tps Util (Rohlf, 2006a) and they were digitised with landmarks using tpsDig2 V2.1 (Rohlf, 2000b). Subsequently, a total of 19 morphometric measurements viz., total length (TL), standard length (SL), fork length (FL), head length (HL), pre-orbital length (PrOL), eye diameter (ED), post-orbital length (PoOL), upper jaw length (UJL), pre-dorsal length (PDL), dorsal fin base length (DFBL), pre-pectoral length (PPrL), pectoral length $(\mathrm{PrL})$, pre-pelvic length $(\mathrm{PPcL})$, pelvic length (PcL), inter-pelvic anal length (IPAL), pre-anal length (PAL), anal fin base length (AFBL), caudal peduncle depth (CPD) and maximum body depth (MBD), were extracted using Paleontological Statistics Software Package for Education and Data Analysis (PAST) (Hammer et al., 2001) (Fig. 2). The size-dependent variation was removed by adopting the widely accepted formula given by Elliot et al. (1995).

$$
\mathrm{M}_{\mathrm{s}}=\mathrm{M}\left(\mathrm{L}_{\mathrm{s}} / \mathrm{L}_{\mathrm{o}}\right)^{\mathrm{b}}
$$

where, ' $\mathrm{M}$ ' is the original morphometric measurement, ' $\mathrm{M}_{\mathrm{s}}$ ' is the morphometric measurement after size correction, ' $\mathrm{L}_{\mathrm{s}}$ ' is the overall mean of the standard length of all the samples, ' $\mathrm{L}_{\mathrm{o}}$ ' is the standard length of the fish and ' $b$ ' is the slope of the regression of $\log \mathrm{M}$ on $\log L_{0}$. A total of 9 meristic traits were extracted from the left lateral aspect of the fish following the widely accepted criteria given by Hubbs and Lagler (1958).

Table 1. Details of $N$. randalli samples collected from various locations along the Indian coast

\begin{tabular}{|c|c|c|c|c|c|}
\hline \multirow{2}{*}{$\begin{array}{l}\text { Coast } \\
\text { Location }\end{array}$} & \multicolumn{2}{|c|}{ East } & \multicolumn{3}{|c|}{ West } \\
\hline & Thoothukudi & Visakhapatnam & Kochi & Mormugao & Mumbai \\
\hline Month of sampling & September, 2018 & September, 2018 & October, 2018 & November, 2018 & October, 2018 \\
\hline No. of samples & 100 & 100 & 100 & 50 & 100 \\
\hline $\begin{array}{l}\text { Total length }(\mathrm{cm}) \\
\text { (mean and range) }\end{array}$ & $\begin{array}{l}19.76 \pm 0.03 \\
(16.48-24.88)\end{array}$ & $\begin{array}{l}18.29 \pm 0.19 \\
(13.50-22.70)\end{array}$ & $\begin{array}{l}10.35 \pm 0.12 \\
(9.33-15.60)\end{array}$ & $\begin{array}{l}12.51 \pm 0.09 \\
(10.39-13.72)\end{array}$ & $\begin{array}{l}17.94 \pm 0.17 \\
(14.58-24.26)\end{array}$ \\
\hline
\end{tabular}

*Values in parentheses indicates the sample size after the removal of outliers

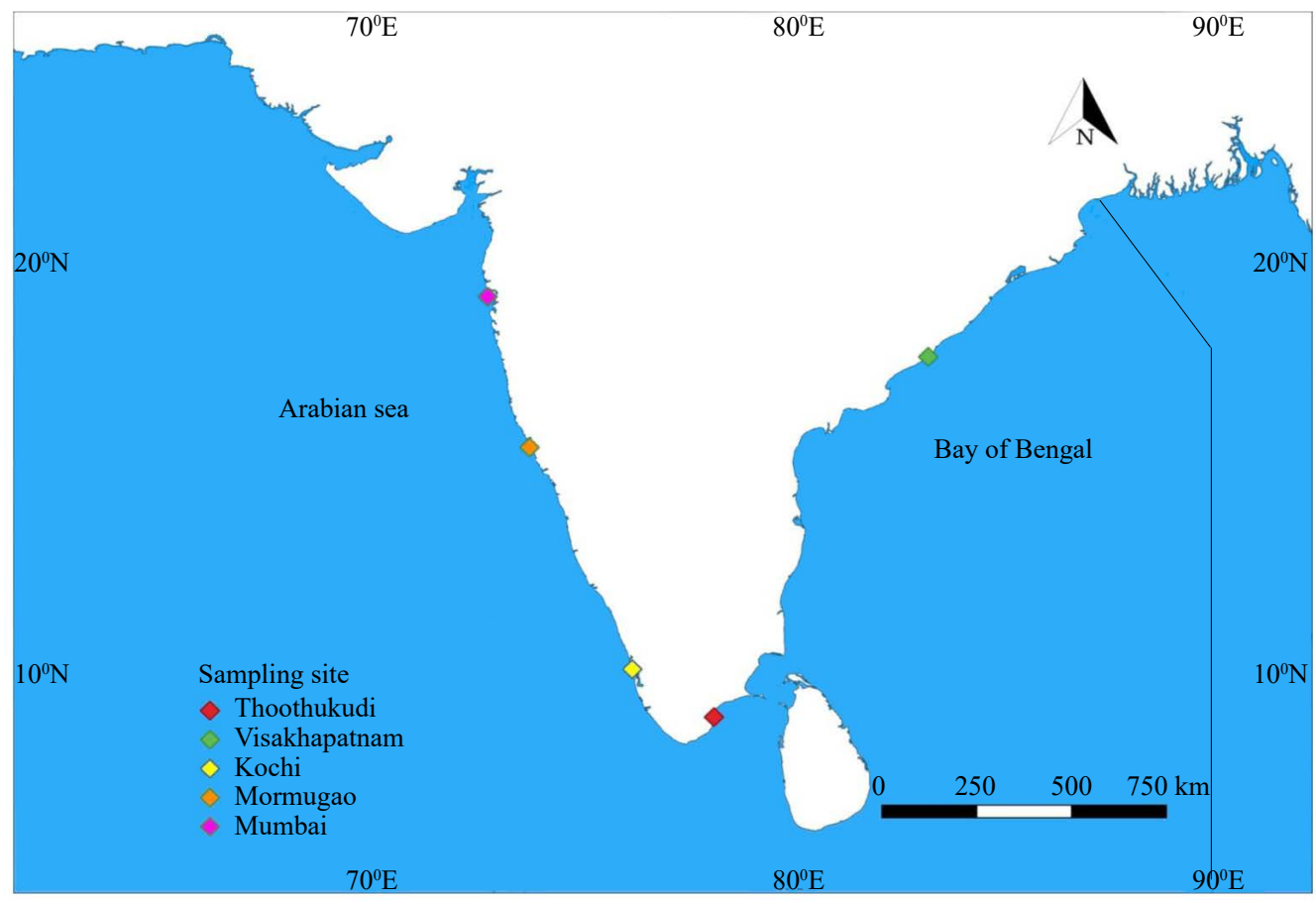

Fig. 1. Map depicting sampling locations of $N$. randalli 


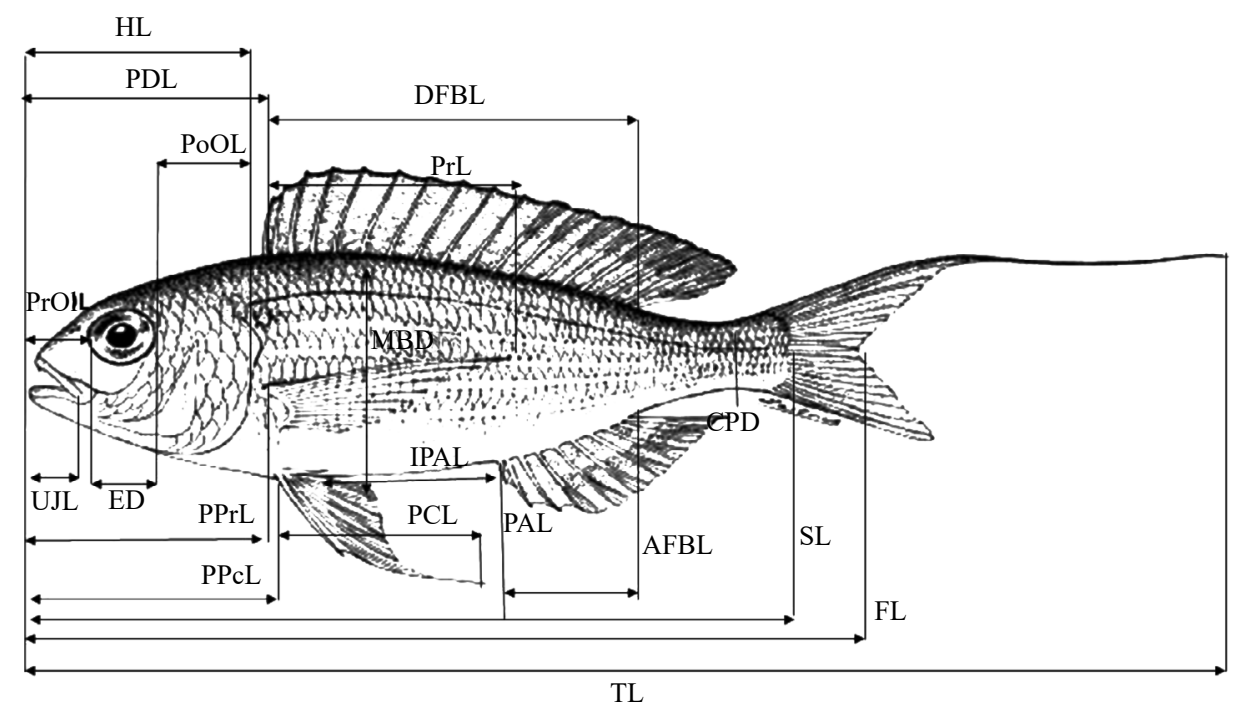

Fig. 2. Morphometric traits of $N$. randalli used in present study

The data were checked for normality and the outliers $(n=36)$ were removed. The morphometric traits were analysed for the difference between the sampling stations using multivariate analysis of variance. The meristic data were subjected to non-parametric Kruskal-Wallis test. Further, the transformed morphometric data were subjected to factor analysis with the principal component method, a data reduction technique commonly used to identify the variables contributing to the variation between the stocks. Discriminant function analysis was used to classify and categorise each specimen to their respective locations based on the factors with higher loadings. All the statistical analyses were done using STATISTICA 12 (Statsoft, 2012)

Multivariate analysis of variance found a significant difference between the samples collected from the 5 different sites along the Indian coast for the extracted morphometric traits $(\mathrm{p}<0.05)$. The initial 4 factors of the factor analysis together explained $66.68 \%$ of the total variations from morphometric characters. The first, second and the third factors contributed to $32.09,14.08$ and $12.31 \%$ of the total variation, respectively. Factor 1 was highly loaded on the eye diameter, head length and pre-pectoral length. High loadings of factor 2 and factor 3 are associated with post-orbital length, caudal peduncle depth, inter pelvic-anal length and anal fin length. The bivariate plot based on the factor scores of morphometric variables showed overlapping of Mumbai and Kochi stocks. Further, Thoothukudi and Visakhapatnam stocks showed demarcation between them (Fig. 3). The discriminant analysis conducted with the factor loadings of more than 0.7 showed the highest classification rate of $80.43 \%$ between the locations. The highest percentage of classification was seen in Mormugao stock (Table 2).

The spine and ray count of dorsal, anal, pelvic fins and the branchiostegal rays were constant among all the sampled locations. Analysis of meristic characters indicated that $N$. randalli possessed 10 dorsal fin spines, 9 dorsal fin rays, 3 anal fin spines, 7 anal fin rays, 1 pelvic fin spine and 5 pelvic fin rays with 6 branchiostegal rays. The species had 15-17 pectoral fin rays and 45-48 lateral line scales and the Kruskal-Wallis test revealed lack of significant difference between the sampling stations of these meristic traits $(p>0.05)$ (Table 3$)$.

Table 2. Percentage of fish classified to their respective locations by discriminant analysis

\begin{tabular}{llllll}
\hline Sampling site & Mumbai & Mormugao & Kochi & Thoothukudi & Visakhapatnam \\
\hline Mumbai & 88.88 & 1.11 & 5.55 & 2.22 & 2.22 \\
Mormugao & 0 & 97.67 & 0 & 2.32 & 0 \\
Kochi & 15.62 & 4.16 & 67.70 & 9.37 & 3.12 \\
Thoothukudi & 4.34 & 3.26 & 15.21 & 67.74 & 9.67 \\
Visakhapatnam & 1.08 & 0 & 3.26 & 5.43 & 90.21 \\
Total rate of classification (\%) & 82.45 & & & & \\
Total rate of misclassification (\%) & 17.55 & & & &
\end{tabular}




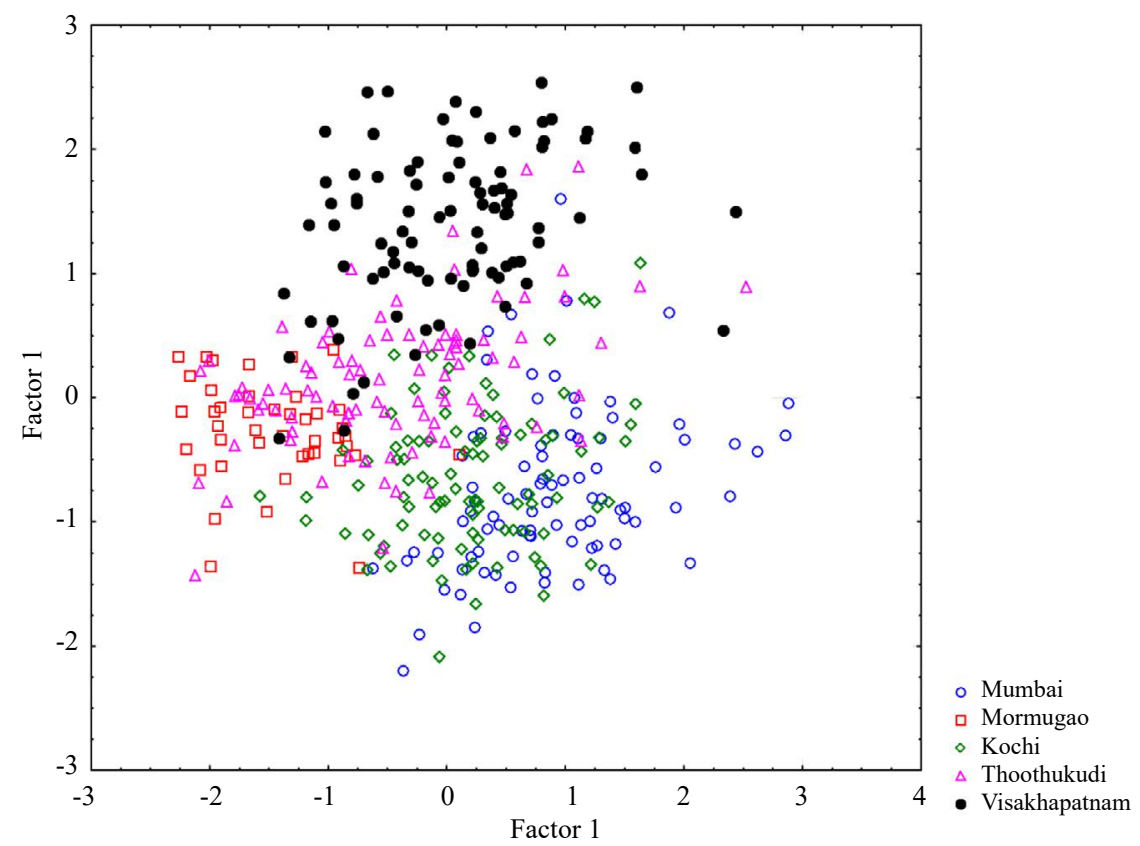

Fig. 3. Scatterplot of factor 1 and factor 2 scores from the morphometric traits of $N$. randalli

Table 3. Summary of meristic traits of $N$. randalli sampled along the Indian coast. Values include range, mode, significance value of the Kruskal-Wallis test and the comparison of meristic traits with published literature

\begin{tabular}{|c|c|c|c|c|c|c|c|c|c|}
\hline $\begin{array}{l}\text { Meristic traits/ } \\
\text { Location }\end{array}$ & Mumbai & Mormugao & Kochi & Thoothukudi & Visakhapatnam & $\begin{array}{l}\text { p-value } \\
\text { Kruskal-Wallis } \\
\text { test }\end{array}$ & $\begin{array}{l}\text { Murty } \\
(1978)\end{array}$ & $\begin{array}{l}\text { John and } \\
\text { Hameed } \\
(1983)\end{array}$ & $\begin{array}{l}\text { Golani and } \\
\text { Sonin (2006) }\end{array}$ \\
\hline Dorsal fin spines & $10(10)$ & $10(10)$ & $10(10)$ & $10(10)$ & $10(10)$ & - & 10 & 10 & 10 \\
\hline Dorsal fin rays & $9(9)$ & $9(9)$ & $9(9)$ & $9(9)$ & $9(9)$ & - & 9 & 9 & 9 \\
\hline Anal fin spines & $3(3)$ & $3(3)$ & $3(3)$ & $3(3)$ & $3(3)$ & - & 3 & 3 & 3 \\
\hline Anal fin rays & $7(7)$ & $7(7)$ & $7(7)$ & $7(7)$ & 7(7) & - & 7 & 7 & 7 \\
\hline Pectoral fin rays & $16(15-17)$ & $16(15-17)$ & $16(15-17)$ & $16(15-17)$ & $16(15-17)$ & 0.28 & $16-18$ & $15-16$ & $15-16$ \\
\hline Pelvic fin spine & $1(1)$ & $1(1)$ & $1(1)$ & $1(1)$ & $1(1)$ & - & 1 & 1 & 1 \\
\hline Pelvic fin rays & $5(5)$ & $5(5)$ & $5(5)$ & $5(5)$ & $5(5)$ & - & 5 & 5 & 5 \\
\hline Branchiostegal rays & $6(6)$ & $6(6)$ & $6(6)$ & $6(6)$ & $6(6)$ & - & - & - & \\
\hline Lateral line scales & $45(45-48)$ & $45(45-48)$ & $46(45-48)$ & $47(45-48)$ & $46(45-48)$ & 0.33 & $45-49$ & 45 & 46 \\
\hline
\end{tabular}

$* \mathrm{p}<0.05$

The present study indicated the presence of different stocks of $N$. randalli along the Indian coast. The difference in the phenotypic characters might be due to geographical separation (Murta et al., 2008). In this study, the significant differences between the stocks were mostly contributed by the eye diameter, head length and caudal peduncle. These characters also contributed to the variations in the stocks of $N$. japonicus, sampled from the Indian coast, which is a confamilial species and occupies the same ecological niche (Sreekanth et al., 2015). Both the Arabian Sea and the Bay of Bengal have their peculiar environment features based on upwelling, salinity and current velocity
(Rao et al., 1992; Kumar et al., 2010). These prevailing environmental conditions play a major role in altering the morphometric traits of respective stocks (Murta, 2000).

Differences in the eye diameter between the stocks may be due to the intensity of light in their habitat during the early developmental stages of fish (Matthews, 1998). A massive influx of sediments from the major Indian rivers into the Bay of Bengal indicates the minimal penetration of solar radiation (Kumar et al., 2010). Hence, variation in eye diameter in fishes from east and west coasts of India could be attributed to the variation in light 
penetration and the associated adaptive development of the species. The difference in the caudal peduncle region of fish stocks along the Indian coast has been observed earlier in various studies (Sajina et al., 2013; Sreekanth et al., 2015). Imre et al. (2002) concluded that the difference in the morphology of the caudal peduncle region of Brook charr was due to the differences in the water velocity. The Bay of Bengal, known for its high-water turbulence than the Arabian Sea, might result in the phenotypic variation in the caudal peduncle. Gatz (1979) suggested that the head-related morphometric traits variations may be due to the differences in prey size. Site-specific differences in the food and feeding biology of $N$. randalli have been previously reported (Raje, 1996; Zacharia and Nataraja, 2003; Joshi, 2005).

Meristic characters are generally set early in the ontogeny and remain constant throughout the lifetime. Our present study indicated lack of plasticity between the meristic traits of $N$. randalli stocks along the Indian coast. Previous studies on the meristic characteristics of N. randalli from Kakinada (Murty, 1978), Kochi (John and Hameed, 1983) and the Mediterranean Sea (Golani and Sonin, 2006) reported results similar to the present study. Meristic characters of N. japonicus (Sreekanth et al., 2013) and N. bipuntatus (Vaisakh, 2013) do not reveal any difference between the stocks along the Indian coast. Hauser and Ward (1998) suggested that the mixing of a few fishes per generation might result in a lack of genetic differentiation. Since there is no geographical barrier between the sampling sites, the lack of differences in the meristic traits might be due to the gene flow between the populations.

It is evident from the present study that there are different phenotypic stocks of $N$. randalli present along the Indian coast. Demographics and stock assessment studies have to be separately conducted for the stocks to provide a stock-specific management advisory. Further, the findings from our present study warrant investigation using molecular markers in order to arrive at a conclusion on the stock structure of $N$. randalli along the Indian coast.

\section{Acknowledgments}

The authors are grateful to the Director, ICAR-CIFE, Mumbai, for encouragement and financial support in the form of fellowship. We extend our gratitude to the staff of ICAR-CMFRI, Kochi and ICAR-CCARI, Goa for providing technical guidance and help in sample collection.

\section{References}

Cadrin, S. X., Karr, L. A. and Mariani, S. 2014. Stock identification methods: Applications in fishery science, $2^{\text {nd }}$ edn. Academic Press, Massachusetts, USA, p.1-5.
Campana, S. E. and Casselman, J. M. 1993. Stock discrimination using otolith shape analysis. Can. J. Fish. Aquat. Sci., 50(5): 1062-1083. DOI: 10.1139/f93-123.

Denney, N. H., Jennings, S. and Reynolds, J. D. 2002. Life-history correlates of maximum population growth rates in marine fishes. Proc. R. Soc. Biol. Sci. Ser. B., 269(1506): 2229-2237. doi: $10.1098 / \mathrm{rspb} .2002 .2138$.

Elliott, N. G., Haskard, K. and Koslow, J. A. 1995. Morphometric analysis of orange roughy (Hoplostethus atlanticus) off the continental slope of southern Australia. J. Fish. Biol., 46(2): 202-220. https://doi.org/10.1111/j.1095-8649.1995. tb059 62.x.

CMFRI 2020. Marine fish landings in India 2019, Technical Report. ICAR-Central Marine Fisheries Research Institute, Kochi, India, p. 1-15.

Gatz, A. J. 1979. Ecological morphology of freshwater stream fishes. Tulane Stud. Zool. Bot., 21(2): 91-124.

Golani, D. and Sonin, O. 2006. The Japanese threadfin bream Nemipterus japonicus, a new Indo-Pacific fish in the Mediterranean Sea. J. Fish. Biol., 68(3): 940-943. DOI: $10.1111 / \mathrm{j} .0022-1112.2006 .00961 . x$.

Gould, S. J. 1966. Allometry and size in ontogeny and phylogeny. Biol. Rev., 41(4): 587-638. doi: 10.1111/j.1469-185x.1966. tb01624.x.

Hauser, L. and Ward, R. D. 1998. Population identification in pelagic fish: The limits of molecular markers. NATO ASI Ser. Ser. A Life Sci., 306: 191-224.

Hammer, O., Harper. D. A. T. and Ryan, P. D. 2001. PAST: Paleontological Statistics Software Package for Education and Data Analysis. Palaeontol. Electron., 4(1): 9 pp.

Hubbs, C. L. and Lagler, K. L. 1958. Fishes of the Great Lakes region, $2^{\text {nd }}$ edn. Cranbrook Institute of Science Bulletin, Michigan, USA, 213 pp.

Imre, I., McLaughlin, R. L. and Noakes, D. L. G. 2002 Phenotypic plasticity in brook charr: Changes in caudal fin induced by water flow. J. Fish. Biol., 61: 1171-1181. doi:10.1006/jfbi.2002.2131.

Jennings, S., Reynolds, J. D. and Mills, S. C. 1998. Life history correlates of responses to fisheries exploitation. Proc. $R$ Soc. Biol. Sci.Ser. B.,, 265(1393): 333-339. doi: 10.1098/ rspb.1998.0300.

John, S. O. P. H. Y. and Shahul Hameed, M. 1983. On the littleknown species of threadfin breams Nemipterus mesoprion (Bleeker) and Nemipterus delagoae (Smith). Fishery Technol., 20(1): 57-62.

Joseph, J. and Jayasankar, P. 2001. Morphometric and genetic variations in the threadfin bream Nemipterus mesoprion. J. Mar. Biol. Ass. India., 43(1\&2): 217-221.

Joshi, K. K. 2005. Biology and population dynamics of Nemipterus mesoprion (Bleeker) off Cochin. Indian. J. Fish., 52(3): 315-322. 
Kumar, S. P., Narvekar, J., Nuncio, M., Kumar, A., Ramaiah, N., Sardesai, S., Gauns, M., Fernandes, V. and Paul, J. 2010. Is the biological productivity in the Bay of Bengal light limited? Curr. Sci., 89(10): 1331-1339.

Matthews, W. J. 1988. Patterns in freshwater fish ecology. Chapman and Hall, New York, USA, 756 pp.

Murta, A. G. 2000. Morphological variation of horse mackerel (Trachurus trachurus) in the Iberian and North African Atlantic: Implications for stock identification. ICES J. Mar. Sci., 57: 1240- 1248. DOI: 10.1006/jmsc.2000.0810.

Murta, A. G., Pinto, A. L. and Abaunza, P. 2008. Stock identification of horse mackerel (Trachurus trachurus) through the analysis of body shape. Fish. Res., 89(2): 152-158. DOI: 10.1016/j.fishres.2007.09.026.

Murty, V. S. 1978. Nemipterus mesoprion (Bleeker, 1853) (Nemipteridae: Pisces); A new record from the seas around India. Indian J. Fish., 25(1\&2): 207-213.

Raje, S. G. 1996. Some observations on the biology of Nemipterus mesoprion (Bleeker) from Veraval (Gujarat). Indian J. Fish., 43(2): 157-162.

Rajesh, K. M., Dineshbabu, A. P., Thomas, S. and Rohit, P. 2014. Fish cutting centres of Karnataka: An ancillary small-scale industry for Surimi production. Mar. Fish. Inf. Ser. T\&E Ser., 222): 8-9.

Rao, D. S., Ramamirtham, C. P., Murty, A. V. S., Muthusamy, S., Kunhikrishnan, N. P. and Khambadkar, L. R. 1992. Oceanography of the Arabian Sea with particular reference to the southwest monsoon. CMFRI Bulletin No. 45, ICAR-Central Marine Fisheries Research Institute, Kochi, India, p. 4-8.

Rohlf, F. J. 2006a. tpsUtil, version 1.38. State University of New York, Stony Brook, New York, USA, http://life.bio.sunysb. edu/morph/index..

Rohlf, F. J. 2006b. tpsDig2, version 2.1. State University of New York, Stony Brook, New York, USA, http://life.bio.sunysb. edu/morph.

Sajina, M., Chakraborty, S. K., Jaiswar, A. K. and Sudheesan, D. 2013. Morphometric and meristic analyses of horse mackerel Megalaspis cordyla (Linnaeus, 1758) populations along the Indian coast. Indian J. Fish., 60(4): 27-34.

Silva, A. 2003. Morphometric variation among sardine (Sardina pilchardus) populations from the north-eastern Atlantic and the western Mediterranean. ICES J. Mar. Sci., 60(6): 1352-1360. https://doi.org/10.1016/S1054-3139(03)00141-3.

Sreekanth, G. B., Chakraborty, S. K., Jaiswar, A. K., Renjith, R. K., Pazhayamadom, D. G., Kamei, G., Vaisakh, G. and Ail, S. S. 2013. Analysis of meristic characters of the Japanese threadfin bream, Nemipterus japonicus (Bloch, 1791) along Indian coast. Indian J. Fish., 60(4): 119-121.

Sreekanth, G. B., Chakraborty, S. K., Jaiswar, A. K., Renjith, R. K., Kumar, R., Sandeep, K. P. and Pazhayamadom, D. G. 2015. Can the Nemipterus japonicus stocks along Indian coast be differentiated using morphometric analysis? Indian J. Geo-Mar. Sci., 44(4): 480-486.

StatSoft 2012. Electronic statistics textbook. StatSoft, Inc., Tulsa, Oklahoma, USA.

Swain, D. P., Hutchings, J.A. and Foote, C. J. 2005. Environmental and genetic influences of stock identification characters. In: Cadrin, S. X., Friedland, K. D. and Waldman, J. R. (Eds.), Stock identification methods - Applications in fishery science. Elsevier Academic Press, Massachusetts, USA, p. 153-172.

Swain, D. P. and Foote, C. J. 1999. Stocks and chameleons: The use of phenotypic variation in stock identification. Fish. Res., 43(1-3): 113-128.

Utter, F. M. 1981. Biological criteria for definition of species and distinct intraspecific populations of anadromous salmonids under the US Endangered Species Act of 1973. Can. J. Fish. Aquat. Sci., 38(12): 1626-1635. https://doi. org/10.1139/f81-212.

Vaisakh, G. 2013. Stock structure analysis of Nemipterus bipunctatus (Valenciennes, 1830) along the Indian coast. M. F. Sc. Thesis, ICAR-Central Institute of Fisheries Education, Mumbai, India.

Zacharia, P. U. and Nataraja, G. D. 2003. Fishery and biology of threadfin bream, Nemipterus mesoprion from MangaloreMalpe. Indian. J. Fish., 50(1): 1-10. 